\title{
Ação mediada e jogos educativos: um estudo junto a alunos do ensino médio em uma aula de Física ${ }^{+*}$
}

\author{
Leandro da Silva Barcellos ${ }^{1}$ \\ Jéssica Adriane de Souza Bodevan ${ }^{1}$ \\ Geide Rosa Coelho ${ }^{1}$ \\ Universidade Federal do Espírito Santo \\ Vitória - ES
}

\section{Resumo}

Esta pesquisa tem como objetivo analisar as interações verbais entre estudantes mediadas pelo jogo de tabuleiro Electron Escape e pela linguagem em uma aula de Física. Tal jogo envolve perguntas cujas respostas devem ser validadas pelos jogadores com base nos modelos cientificos contidos nas cartas. Diante disso, interessa-nos saber: como os alunos conduzem a partida mediada pelo jogo e pela linguagem? Quais as potencialidades de Electron Escape, enquanto recurso, para o ensino da Física? Para tanto, realizamos uma pesquisa qualitativa e do tipo estudo de caso em uma turma da primeira série do ensino médio de uma escola da rede estadual de Vila Velha, Espírito Santo, no último trimestre de 2018. Os estudantes foram divididos em grupos e disputaram uma partida de Electron Escape. Coletamos as interações verbais por meio de registros de áudio. O processo analítico apoiou-se na perspectiva sociocultural. Os resultados mostram que o jogo estimulou o resgate de conteúdos e a utilização da linguagem cientifica escolar na construção das respostas, podendo contribuir para a revisão do conteúdo de Física. Os alunos modificaram o sistema de jogo de competitivo para cooperativo. Além disso, o rigor estabelecido para validação das respostas foi baixo, de modo que modelos incorretos foram aceitos. Consideramos que esses resultados trazem contribuições importantes para o repensar na forma de utilização do jogo Electron Escape e no papel do professor no uso de meios mediacionais.

\footnotetext{
${ }^{+}$Mediated action and educational games: a study with high school students in a physics classroom

* Recebido: 5 de março de 2020. Aceito: 13 de janeiro de 2021.

${ }^{1}$ E-mails: leandrobarcellos5@gmail.com; jessicabodevan@icloud.com; geidecoelho@gmail.com
} 
Palavras-chave: Ensino de Física; Jogos Educativos; Ação Mediada.

\begin{abstract}
This research aims to analyze the verbal interactions of students mediated by the board game Electron Escape and the language in a physics' classroom. This game involves questions with answers should be validating by players on the basis of scientific models in the cards of the game. Therefore, it is of our interest to know: how the students lead the match mediated by the game and the language? What are the game's potentialities, as a resource, for the physics teaching? For this, we realize a qualitative and case study research in the first year High School students in a public school in Vila Velha, Espirito Santo, in the last trimester of 2018. The students were divided in groups to play Electron Escape. The verbal interactions were collected as audio recordings. The analytics' process relied on sociocultural perspective. The results show that the board game encouraged the rescue of contents and the use of scientific terms in the elaboration of answers. It may contribute to revision of the physics' content. The students changed the game's system from competitive to cooperative. Also, the students establish low rigor to validation the answers and so incorrect models were accepted. We consider that the results bring about an important contribution to rethink about the ways of use Electron Escape and the teacher's role for the use of mediacional means.
\end{abstract}

Keywords: Physics Teaching; Educational Games; Mediated Action.

\title{
I. Introdução
}

O uso de jogos como recurso para o ensino de Ciências da Natureza tem sido explorado em pesquisas nacionais e internacionais (VARGENS; NIÑO-EL-HANI, 2011; SOUZA; MELLO, 2017; VILAS BOAS; MACENA JUNIOR; PASSOS, 2017; LUDOVICO, 2017; DZIOB, 2018; OLMSTEAD, 2019). Tais pesquisas defendem o jogo como alternativa atraente para os estudantes, e descrevem potencialidades relacionadas ao engajamento em determinados aspectos do conhecimento científico, além de sinalizarem para a relação positiva entre o uso de jogos e uma melhora no processo de ensino-aprendizagem.

De acordo com Melo (2015) o jogo em sala de aula pode auxiliar, de maneira prazerosa, no levantamento de conhecimentos prévios, despertar do interesse dos alunos e exploração de conceitos. 
No que diz respeito à Física, os jogos apresentam grande potencial para despertar o interesse dos alunos pelos conteúdos, principalmente porque os jogos abordam esses conteúdos dentro de um ambiente lúdico, propício a uma melhor aprendizagem, muito diferente das salas de aula nas escolas, que geralmente são expositivas, tornando o ambiente um espaço de "anti-criação", impedindo uma maior participação dos alunos nas aulas (PEREIRA, 2007, p. 176).

O aspecto lúdico dos jogos permite que os participantes experimentem comportamentos incompatíveis com situações normais, ou seja, eles podem ficar brevemente à margem da realidade e reelaborá-la. Durante o jogo os participantes podem imergir em uma "bolha lúdica", na qual existem regras próprias e procedimentos específicos, porém mutáveis. Nesse contexto os jogadores podem viver experiências enriquecedoras, sem consequências, julgamentos por erros ou punições do mundo exterior. Esse "isolamento", criado pela "bolha lúdica", mantém o jogador concentrado nas ações a serem realizadas na partida, estimulando a atenção, foco, disciplina, autocontrole, estratégia e possibilitando a assimilação de conceitos. Ademais, os jogos podem promover a oportunidade de os estudantes exercitarem a lógica, o raciocínio e habilidades para solucionar problemas de diferentes formas, ao contrário do que normalmente é exigido em exercícios tradicionais e provas de Ciências (PEREIRA, 2008).

Diferentes pesquisas empíricas têm apontado para esta direção. Ludovico (2017) utilizou um jogo de cartas, elaborado por ela para trabalhar conceitos de Física de partículas com estudantes da primeira série do ensino médio. A autora concluiu que o uso desse recurso potencializou a aquisição de conhecimentos conceituais, procedimentais e atitudinais por parte dos alunos. Também foram contemplados elementos relativos à cooperação e respeito às regras.

Souza e Mello (2017) utilizaram jogos clássicos, como cruzadinhas, caça-palavras e jogo dos sete erros, como ferramentas para avaliar estudantes do ensino médio em meio a uma sequência didática sobre hidrodinâmica. Os pesquisadores afirmam que por meio desse recurso os alunos foram capazes de pôr em prática os conhecimentos construídos ao longo das aulas, e que esta estratégia de avaliação se mostrou uma via interessante para se fazer emergir novas ideias científicas e minimizar alguns problemas de aprendizagem.

Em uma pesquisa realizada com estudantes do ensino médio, nas modalidades regular e Educação de Jovens e Adultos, Bodevan e Daher (2020) propuseram aos alunos a produção e aplicação de jogos visando retomar conceitos sobre processos de propagação de calor que já tinham sido trabalhados por meio de aulas expositivas. As autoras afirmam que essa estratégia favoreceu uma melhor apropriação dos conhecimentos que circularam na sala de aula, e reconhecem que a utilização de jogos no contexto escolar potencializa tanto a promoção da aprendizagem quanto uma maior interação aluno-aluno e aluno-professor. Isto é, os jogos educativos "podem ser a ponte entre o professor e o aluno, em que ambos buscam o mesmo objetivo, a aprendizagem divertida e com alegria" (BODEVAN; DAHER, 2020, p. 195). 
As pesquisas apresentadas até aqui ratificam o potencial do jogo como recurso para o processo de ensino e aprendizagem em sala de aula. Entretanto, existem estudos que sinalizam para uma carência de fundamentação teórica mais aprofundada em trabalhos envolvendo o uso de jogos. O aspecto motivacional do lúdico é comumente exaltado, aliado à intuição de que o jogo contribui para o aprendizado, mas de forma ateórica (CUNHA, 2012; GARCEZ, 2014; NETO; MORADILLO, 2016; SILVA et al., 2017).

$\mathrm{O}$ jogo, bem como outros recursos de ensino, tem suas potencialidades condicionadas à forma como é articulado ao trabalho docente. Este recurso deve estar inserido em um contexto mais amplo, baseado nos objetivos educacionais estabelecidos pelo professor. Caso contrário, corre-se o risco de o jogo ser visto como um mero passatempo para preencher situações como as de aula vaga. Esse entendimento é necessário para que não supervalorizemos a ferramenta em relação a quem a opera, de modo a reconhecer a dimensão social atrelada ao jogo, na qual a interação entre seres humanos é essencial para o processo de aprendizagem utilizando tal recurso.

Reconhecemos que é preciso avançar na compreensão de como o emprego de jogos pode contribuir para o aprendizado dos estudantes. Para tanto, assumimos a linguagem como elemento fundamental deste processo, ancorados em pesquisadores da escola Vigotskiana. Logo, estudantes interagindo em uma aula mediada pela linguagem e um jogo pode se constituir como um cenário propício para discutir o processo coletivo de significação. Nessa perspectiva, segundo Rezende e Trindade (2011), a linguagem é entendida como construto sociocultural, fonte social de um grupo e meio mediacional do processo de construção de significados.

O objetivo desta pesquisa é analisar as interações verbais entre estudantes mediadas pelo jogo de tabuleiro Electron Escape e pela linguagem em uma aula de Física. Tal análise foi feita sob a luz da perspectiva sociocultural. Buscamos, ainda, caracterizar a mediação estabelecida pelos alunos durante a disputa de uma partida do jogo, com base na Teoria da Ação Mediada de Wertsch (1999), e, a partir disso, interessa-nos saber: como os alunos conduzem a partida mediada pelo jogo e pela linguagem? Quais as potencialidades de Electron Escape, enquanto recurso, para o ensino da Física?

\section{O jogo como meio mediacional para o ensino de Ciências}

Rocha e Gois (2017) reconhecem que é difícil conceituar jogo em virtude da pluralidade de significados existentes, mas afirmam que é necessário buscar uma concepção de jogo que possibilite maior aproximação das concepções de Wertsch.

De acordo com Szundy (2009), Vigotski (1994) e Leontiev (1988) entendem o jogo como uma atividade importante nos processos de aprendizagem e desenvolvimento da criança, pois possibilita, entre outras coisas, a interação com o mundo social. Nesta interação, a criança pode compreender as regras e as relações sociais necessárias para sua integração 
naquele contexto. Ainda sobre a relação jogo-desenvolvimento ${ }^{2}$, Vigotski (1994) afirma que ela possibilita a criação de zonas de desenvolvimento proximais, as quais levam o jogador a interagir socialmente de acordo com as regras do jogo. Estas, por vezes, serão opostas às necessidades imediatas das crianças. Portanto, o processo de aprendizagem e desenvolvimento com jogos será conflituoso. Todavia, tais conflitos com as regras e as interações sociais com os outros estarão presentes durante toda a vida social.

Ainda segundo esses pesquisadores soviéticos, citados por Szundy (2009), o jogo também permite que o jogador se imagine em interações sociais que não a imediata, projetando ações e possibilidades, estimulando a capacidade de abstração essencial para o processo de aprendizagem de conhecimentos científicos. É na discrepância entre a ação e a operação que se origina a imaginação. A ação seria o conteúdo do jogo, enquanto a operação seria o modo de agir no jogo. Durante a partida o jogador adapta seu modo de agir de acordo com as limitações do meio mediacional, como as regras impostas pelo jogo.

As regras são compreendidas como um aspecto constitutivo do jogo. Não é possível jogar sem regras, uma vez que estas orientam as ações. "Não existe brinquedo sem regras. A situação imaginária de qualquer forma de brinquedo já contém regras de comportamento, embora possa não ser um jogo com regras formais estabelecidas a priori" (VIGOTSKI, 1994, p. 124-125).

As regras nos permitem conceituar os jogos regrados, que são aqueles que possuem as regras como conteúdo fixo. Nos jogos regrados as ações e comportamentos dos jogadores estão condicionados por regras, as quais determinam o que é ou não aceitável. Tais regras orientam as ações verbais e não verbais de forma semelhante às regras que regulamentam as ações e interações humanas nas mais diversas esferas sociais. Por exemplo: em um jogo de tabuleiro é inaceitável apenas jogar o dado e andar o número de casas correspondentes, visto que cada jogada exige do participante uma ação de linguagem e, consequentemente, capacidades de operar com ela, determinadas pelas regras do jogo (SZUNDY, 2009).

Newman e Holzman (2002) afirmam que nos jogos regrados as regras representam o “como fazer", e a orientação para o resultado do jogo é separada do desempenho, ainda que o resultado esteja diretamente relacionado ao desempenho do jogador. Os jogos regrados se iniciam na infância e permanecem ao longo da vida. Existem muitos tipos de jogos regrados e, assim como as competições esportivas, os jogos educativos também podem ser incluídos nesse arcabouço. Eles se diferenciam dos demais em virtude de seus propósitos pedagógicos, os quais são estabelecidos intencionalmente e determinam a natureza, os objetivos e as regras do jogo.

\footnotetext{
${ }^{2}$ Segundo Szundy (2009), Vigotski (1994) utiliza o termo 'brinquedo-desenvolvimento', em que brinquedo pode ser entendido como atividade lúdica, o que inclui jogos de papéis, protagonizados, de regra etc. Assim, brinquedo, enquanto termo genérico, pode assumir o mesmo sentido de jogo.
} 
Entendemos o jogo educativo como um meio mediacional com grandes potencialidades a ser incorporado nas estratégias de ensino. Enfocando no contexto do ensino de Ciências da Natureza, Rocha e Gois $(2017$, p. 7) compreendem que os jogos educativos

[...] constituem-se importantes ferramentas culturais pelas quais os alunos podem se apropriar do conhecimento cientifico. Uma vez que o desenvolvimento das habilidades especificas surge por meio da experiencia, os estudantes podem se apropriar do conhecimento científico jogando e exercitando a linguagem científica.

Wertsch (1999) afirma que o desenvolvimento de determinadas habilidades específicas surge da experiência. Logo, é preciso criar oportunidades para que os agentes atuem com as ferramentas culturais, permitindo-lhes tomar consCiência sobre seus usos e, assim, identificar e modificar as formas de mediação indesejáveis. Isso porque "a percepção de que novas ferramentas culturais transformam a ação mediada e o entendimento de como essas transformações ocorrem é fundamental para o processo de domínio e apropriação por parte dos estudantes" (PEREIRA; OSTERMANN, 2012, p. 36). Desse modo, é importante que o professor promova atividades que envolvam discussões em grupos e resolução de problemas por meio de ferramentas culturais, as quais, segundo Giordan (2008), devem ser oferecidas em um determinado contexto para que os agentes as utilizem para estabelecerem interações uns com os outros.

O jogo pode ser entendido como uma ferramenta histórica e culturalmente situada. Há registro do uso de jogos em diferentes culturas ao longo do tempo, cada qual com seu tipo e intencionalidade: no século II a. C., na Grécia, Aristóteles sugeriu a utilização de jogos para que as crianças pudessem imitar atividades adultas como forma de preparação para a vida futura; na Roma antiga (I a. C. a I d. C) o jogo destinava-se ao preparo físico, objetivando a formação de soldados e cidadãos obedientes; no século XVIII, iniciou-se uma popularização dos jogos e o surgimento dos primeiros jogos voltados para o ensino de Ciências; no século XIX os jogos começaram a ter mais espaço e aceitação no contexto educacional e, atualmente, é possível encontrar pesquisas e eventos acadêmicos dedicados ao estudo dessa ferramenta (CUNHA, 2012).

Entender o jogo como uma ferramenta cultural nos permite enxergar estudantes disputando uma partida como sendo agentes-agindo-com-meios-mediacionais, visto que a ação humana é mediada por meios mediacionais (ou ferramentas culturais) que estão disponíveis em um determinado contexto sociocultural (PEREIRA; OSTERMANN, 2012). Além disso, Wertsch (1999) sinaliza para a existência de uma tensão irredutível entre os indivíduos e os meios mediacionais que eles empregam, sendo inadequado desatrelar a ação dos meios utilizados para mediá-la. 
Existem diferentes jogos, os quais apresentam uma variedade de formas, tipos e objetivos. Podemos dizer que eles oferecem affordances ${ }^{3}$, as quais serão delimitadas pelo contexto e intencionalidade dos agentes (OLIVEIRA; RODRIGUES, 2006). Enfocando no contexto educacional, é possível criar jogos com fins pedagógicos ou adaptar um determinado jogo para o contexto educativo, o que se aproxima da propriedade spin-off $^{4}$ da ação mediada de Wertsch, que se relaciona a utilização de objetos na mediação para fins diferentes daqueles para os quais foram pensados ou produzidos (OLIVEIRA; SÁ; MORTIMER, 2019).

Nesta pesquisa utilizamos o jogo de tabuleiro Electron Escape, que foi concebido para ser uma ferramenta no processo de ensino-aprendizagem de Física. Ele pode ser classificado como um meio mediacional de materialidade permanente, já que permanece existindo mesmo quando não está sendo utilizado em mediações. Além de Electron Escape, a mediação também ocorre por meio da linguagem, cuja materialidade é instantânea (OLIVEIRA; SÁ; MORTIMER, 2019). É importante frisar que Wertsch (1999) considera que a materialidade é uma propriedade de qualquer meio mediacional, incluindo a linguagem.

$\mathrm{O}$ uso de ferramentas culturais pode ser caracterizado como ação mediada. Pereira e Ostermann (2012) reconhecem que esta é a unidade de análise ideal para o estudo do funcionamento humano, como por exemplo, a elaboração de significados a partir dos meios mediacionais, como as ferramentas e a linguagem, disponíveis em dado contexto. A compreensão de um contexto envolve cinco termos: (i) ato (ação), que se refere a o que ocorreu na ação ou no pensamento; (ii) cena (contexto), que representa a situação em que ocorreu; (iii) agente, que é o sujeito que realiza a ação ou o pensamento; (iv) propósito, que sinaliza para a intenção do agente; e (v) agência, que são as ferramentas socioculturais utilizadas (WERTSCH, 1999). Trazzi (2015) sinaliza para a importância desses elementos ao considerar que eles possibilitam a análise do contexto em que a ação mediada se delineia.

Para Alves (2011) o jogo deve ser compreendido como um processo medial, mais que um simples instrumento. $\mathrm{O}$ mesmo pesquisador defende que a relação do jogador com 0 jogo é singular, sendo inadequado compreender o sentido do jogo de forma desarticulada do jogador e vice-versa. Utilizamos esses pressupostos para caracterizar a mediação de estudantes durante a realização de uma partida do jogo Electron Escape buscando contemplar os sujeitos, as ferramentas culturais e o contexto para uma compreensão mais ampla. Isso porque a teoria de Wertsch não visa a explicar o que ocorre na "cabeça do sujeito", e sim analisar a ação humana e os aspectos a ela atrelados, como os meios mediacionais (RIBEIRO, 2018).

O jogo, enquanto meio mediacional de materialidade permanente, possibilita e estimula o uso da linguagem de acordo com as regras. Os jogos educativos que enfoquem na

\footnotetext{
${ }^{3} \mathrm{O}$ conceito de affordances designa "as propriedades ambientais disponíveis a certo indivíduo ou espécie animal, que permitem ou restringem a sua ação" (OLIVEIRA; SÁ; MORTIMER, 2019, p. 253).

${ }^{4} \mathrm{O}$ conceito de spin-off está atrelado à noção de que os objetos materiais podem ser utilizados para fins diferentes daqueles para os quais foram pensados ou produzidos (OLIVEIRA; SÁ; MORTIMER, 2019).
} 
utilização da linguagem, por parte dos estudantes, nos permitem estabelecer uma correlação com o processo de aprendizagem com base na perspectiva sociocultural.

Segundo Marx; Engels (2007, p. 53), citados em Lopes Júnior; Moraes; Gonçalves (2020), “[...] a linguagem nasce, assim como a consCiência, da necessidade, da carência de intercâmbio com os demais homens". Ou seja, a função primeira da linguagem é ser um meio de comunicação social, de enunciação e compreensão (VIGOTSKI, 2009). Segundo Luria (1991) a linguagem é composta por um sistema de códigos que nos permite designar objetos, ações, qualidades e as possíveis inter-relações entre quaisquer desses aspectos, além de possibilitar a transmissão de informações construídas historicamente.

\section{[...] a comunicação, estabelecida com base em compreensão racional e na intenção de transmitir ideias e vivências, exige necessariamente um sistema de meios cujo protótipo foi, é e continuará sendo a linguagem humana, que surgiu da necessidade de comunicação no processo de trabalho (VIGOTSKI, 2009, p. 11).}

Dada a necessidade de comunicação, a palavra em si passa a se referir a uma classe de objetos, ao invés de algo isolado. Assim, "[...] cada palavra é uma generalização latente, toda palavra já generaliza e, em termos psicológicos, é antes de tudo uma generalização" (VIGOTSKI, 2009, p. 9). A comunicação por meio da linguagem é possível por aqueles que compreendem o significado dos códigos linguísticos. Logo, o emprego funcional do signo será uma função primordial da linguagem. Conforme as necessidades sociais se transformam, renovam e se ampliam, a linguagem paulatinamente se altera, se desenvolve, na medida em que o trabalho se torna mais complexo e exige comunicação.

A linguagem é uma das funções psicológicas superiores na qual o emprego dos signos é meio principal para o domínio dos processos psíquicos (VIGOTSKI, 2009). O uso da palavra é fundamental para o distanciamento entre sujeito e objeto gerido pelo processo de trabalho, o que só tem sentido nas interações sociais. Ao nomear um objeto ou fenômeno com uma palavra (ou um conjunto delas), podemos discriminá-lo, dirigir atenção e conservá-lo na memória, podendo trabalhar com ele mesmo em sua ausência, o que embasa o processo de abstração e generalização (LURIA, 1991).

Para Vigotski (2009), no processo de conceituação, o signo é o meio para análise e classificação de objetos e fenômenos, com vistas à formação do conceito. Posteriormente, ele será convertido em seu símbolo. Desta forma, a linguagem se torna um meio mediacional que possibilita a comunicação e a via para o pensamento. Enquanto meio mediacional, a linguagem possibilita ao indivíduo

[...] dominar um ciclo imensurável de conhecimentos, habilidades e modos de comportamento, que em hipótese alguma poderiam ser resultado da atividade independente de um individuo isolado. Isto significa que com o surgimento da linguagem surge no homem um tipo inteiramente novo de desenvolvimento psíquico desconhecido dos animais, e que a linguagem é realmente o meio mais importante para o desenvolvimento da consCiência (LURIA, 1991, p. 81). 
A linguagem é o principal meio mediacional das ações humanas. Ela possibilita a abstração de propriedades condicionantes de problemas a serem solucionados, o raciocínio sistematizado e o exercício intelectual de análise de fenômenos (MARTINS, 2016). É por meio de interações sociais mediadas principalmente pela linguagem que o sujeito consegue se apropriar do conhecimento acumulado historicamente e compreender o mundo. Logo, se apropriar das palavras e dos conceitos é a via para a libertação da imposição da natureza.

O conceito é impossivel sem palavras, o pensamento em conceito é impossivel fora do pensamento verbal; em todo esse processo, o momento central, que tem todos os fundamentos para ser considerado causa decorrente do amadurecimento de conceitos, é o emprego específico da palavra, o emprego funcional do signo como meio de formação de conceitos (VIGOTSKI, 2009, p. 170).

O signo e o conceito possuem uma estrutura social, e se constituem nos problemas sociais aos quais os indivíduos estão atrelados. Ou seja, a incorporação de instrumentos e signos e atividades sociais estão imbricadas (VIGOTSKI, 2009). Isto posto, ao pensarmos no processo educativo, a aquisição da linguagem, por parte dos estudantes, deve estar associada a atividades sociais, como, por exemplo, a disputa de uma partida de um jogo. Especialmente no caso de um jogo educativo voltado para o ensino de Física que estimula a utilização da linguagem da Ciência escolar.

A Ciência pode ser compreendida como uma cultura que possui uma maneira própria de pensar e falar sobre o mundo natural, e a introdução do estudante nessa cultura envolve aprender a lidar com as ferramentas da comunidade científica, como a linguagem (MORTIMER; SCOTT, 2003). O ensino de Ciências que visa à enculturação deve buscar a apropriação, por parte dos estudantes, dessas ferramentas, por meio das interações sociais na sala de aula, que são mediadas pela utilização de meios mediacionais, como a linguagem e as próprias ferramentas. $\mathrm{O}$ jogo não é uma ferramenta cultural típica da cultura científica escolar, mas tem sido cada vez mais utilizado como meio mediacional nas escolas, integrando-se, paulatinamente, a essa cultura.

Assumindo que a cultura científica escolar se constituiu por meio do encontro entre culturas, o jogo é apresentado aqui como meio mediacional importante no processo de ensino e aprendizagem da Física, entendendo que potencializa interação, cooperação e colaboração entre os jogadores (estudantes) e com professor. Consideramos essas dimensões fundamentais no processo de aprendizagem, pois são elementos que se aproximam da perspectiva da sala de aula de Ciências como espaço social, se constituindo por normas e práticas. Ao assumirmos a aprendizagem em Ciências como processo de enculturação reconhecemos que

[...] o conhecimento e o entendimento, inclusive o entendimento científico, são construídos quando os indivíduos se engajam socialmente em conversações e atividades sobre problemas e tarefas comuns. Conferir significado é, portanto, um processo dialógico que envolve pessoas em conversação [...] (DRIVER et al. 1999, p. 34). 
Assim, o jogo pode atuar como elemento que engaja os estudantes nesse processo de conversação e negociação, os quais potencializam o uso da linguagem científica escolar. Para Lemke (1990) o aprendizado em Ciências consiste em aprender a usar a linguagem científica para ler, escrever, solucionar problemas e desempenhar atividades práticas. Este autor defende que não se deve restringir o ensino a definição de conceitos e equações, sendo necessário que os alunos aprendam a combinar os significados dos diferentes termos conforme os modos de falar validados pela Ciência.

Almeja-se que, conforme os estudantes se apropriem da Ciência escolar, tornem-se capazes de empregar os termos científicos para construir seus argumentos. $\mathrm{O}$ uso de termos da Ciência pode ocorrer de maneira nominativa, ou seja, apenas para fins de comunicação, dar nome a um processo ou fenômeno. Tal uso da palavra corresponde a uma operação que precede o pensamento conceitual. Neste, quando desenvolvido, a palavra é utilizada de modo discriminado, consciente, assumindo uma função semântica (SEPULVEDA et al., 2011). Nesse viés, não podemos considerar a mera repetição do discurso escolar como indício de aprendizado, sendo necessário avaliar o emprego dos conceitos, pelos estudantes, em situações problemáticas nas quais o conhecimento científico é requerido e avaliado.

Diante do que foi discutido até aqui, ratificamos nosso posicionamento de que um jogo educativo regrado voltado para o ensino de Física, como Electron Escape, pode ser um aliado importante no processo de ensino-aprendizagem da Ciência escolar. Isto porque as ações utilizando a linguagem do jogo estarão relacionadas com a linguagem da Ciência escolar, ou seja, esta cultura determinará as regras do jogo. Conforme os jogadores precisam lidar com problemas para avançar na partida, eles poderão exercitar a linguagem científica escolar. Assim, o jogo torna-se um meio mediacional de materialidade permanente complementar à linguagem, que possui materialidade instantânea, em que ambos comporão a cena de uma aula de Ciências, contexto adequado para a promoção do aprendizado da linguagem científica.

\section{O jogo Electron Escape}

O jogo educativo que utilizamos foi Electron Escape, cuja concepção ocorreu no contexto de um projeto da Universidade Federal do Espírito Santo, a partir da sugestão de alguns bolsistas em parceria com o professor orientador ${ }^{5}$ de uma atividade extensionista. Electron Escape possui elementos alusivos à Física Atômica, criados para estimular a imersão dos jogadores que assumem o papel de 'elétrons' que estão 'aprisionados' pelo núcleo do átomo. Destacam-se os quarks em seu interior (Fig. 1), e regras como "o princípio da exclusão", que impede que dois jogadores (elétrons) ocupem uma mesma casa simultaneamente. Salientamos que o jogo não se restringe aos conteúdos de Física Atômica, e

\footnotetext{
${ }^{5}$ Agradecemos a Thieberson Gomes e a Tyrone Quintela Júnior que, juntamente com o primeiro autor deste texto, criaram o jogo Electron Escape no contexto do Programa Institucional de Bolsas de Iniciação à Docência (Pibid) em 2013.
} 
que elementos como o nome do jogo, a aparência do tabuleiro e algumas regras relativas ao átomo foram apenas recursos lúdicos.

O jogo é composto pelo tabuleiro, um conjunto de cartas de perguntas e respostas (112 conceituais e 74 contextualizadas) sobre os diferentes campos da Física estudados na educação básica, um conjunto de 'cartas de poder', um dado de dez faces e cinco pinos, que devem ser utilizados pelos jogadores para percorrer o tabuleiro. Este consiste em uma peça circular composta por quatro trilhas concêntricas divididas em casas, as quais devem ser percorridas pelos participantes que saem da região mais interna (começando na casa 'Início') em direção a mais externa (casa 'Liberdade'). Vence o primeiro a completar tal trajeto. O objetivo é responder corretamente as perguntas de Física para ganhar energia e, assim, avançar para 'escapar do aprisionamento'.

A partida se inicia com os jogadores disputando no dado quem começa. Aquele que tirar o maior número é o primeiro, aquele que tirar o segundo maior número é o segundo e assim sucessivamente, pois o jogo funciona por turnos. A cada rodada o jogador da vez lança o dado e sorteia uma carta contendo uma pergunta, e pode escolher se deseja ou não responder. A validação da resposta (correta ou incorreta) dada pelo jogador da vez é feita pelos outros jogadores baseados na resposta contida na própria carta sorteada. Caso responda corretamente o jogador avança o número de casas obtido no dado. Caso erre ou opte por não responder, ele permanece no mesmo lugar. A inexistência de penalidades a quem erra ou opta por não responder foi estabelecida para estimular os estudantes a, no mínimo, tentarem formular uma resposta, divergindo da perspectiva de punição ao erro.

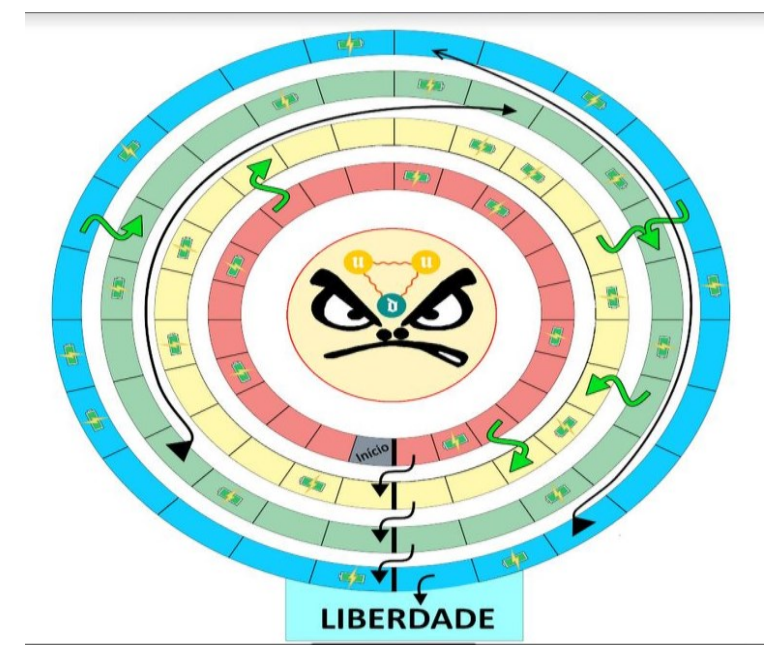

Fig. 1 - Versão atual do tabuleiro do jogo Electron Escape. Fonte: os autores. 
Tabela 1 - Casas especiais do tabuleiro do jogo Electron Escape. Fonte: os autores.

\begin{tabular}{|c|l|}
\hline $\begin{array}{c}\text { Casas } \\
\text { especiais }\end{array}$ & \multicolumn{1}{|c|}{ Funcionamento } \\
\hline Cartas de & $\begin{array}{l}\text { Se ao avançar ou recuar no tabuleiro o jogador parar em uma casa com } \\
\text { esse símbolo, ele deve pegar uma Carta de Poder no topo do monte e } \\
\text { poderá usá-la quando quiser, em si mesmo ou em um adversário. } \\
\text { Exemplo de carta de Poder: } \\
\text { Carta RUV - Você pode utilizar os fótons de Radiação Ultravioleta (RUV) } \\
\text { para avançar 3 casas ou fazer um oponente recuar 3 casas no tabuleiro. }\end{array}$ \\
\hline Túnel 1 & $\begin{array}{l}\text { As casas com setas verdes funcionam como "túneis" que levam o jogador } \\
\text { para a casa indicada pela ponta da seta. Elas permitem que o jogador mude } \\
\text { de camada mais rapidamente. } \\
\text { Cuidado: Ela pode te fazer avançar ou recuar, portanto, use com } \\
\text { inteligência! }\end{array}$ \\
\hline Túnel 2 & $\begin{array}{l}\text { Essas casas funcionam de modo parecido com as setas verdes, porém, } \\
\text { deslocam o jogador somente entre casas da mesma camada. Ao parar na casa } \\
\text { com o símbolo ao lado, o jogador deve mover-se automaticamente para a casa } \\
\text { indicada pela ponta da seta. }\end{array}$ \\
\hline
\end{tabular}

Electron Escape contempla a dimensão conceitual, necessária para responder as questões, mas também elementos de sorte, como o uso de um dado de dez faces e a aleatoriedade das perguntas, além de estratégia e lógica, relacionadas à escolha por responder ou não as questões, utilização e combinação das cartas de poder e os túneis contidos no tabuleiro. Desta forma, a competição é acentuada por meio de elementos de lógica, estratégia e sorte, o que contribui para que o jogo seja mais atrativo.

Electron Escape possui dois tipos de perguntas: as puramente conceituais, em que as respostas se resumem a um conceito, como por exemplo, "Qual o tipo de Colisão em que a energia cinética se conserva e os corpos se separam após o choque?”; e as aplicadas, nas quais os conceitos científicos são exemplificados em situações familiares aos estudantes, como por exemplo, "Por que precisamos fazer dois furos em uma lata de leite condensado para que ele saia?". Para este estudo selecionamos perguntas de ambos os tipos, desde que envolvessem os conteúdos já trabalhados em sala pela professora, a saber: cinemática, dinâmica, energia, gravitação e pressão.

Todas as cartas contêm um modelo de resposta, a qual deve ser comparada ao modelo elaborado pelo jogador da vez. Cabe ao grupo realizar o processo de validação, mas o professor pode intervir se solicitado ou julgar pertinente. Dessa forma, evita-se que o docente precise acompanhar de perto todos os grupos.

Entendemos Electron Escape como um jogo regrado, no qual as ações verbais e não verbais são determinadas pelo conhecimento científico escolar. Ou seja, as regras do jogo e a validação das respostas estão fundamentadas nos entendimentos aceitos por esta cultura. Durante a partida os estudantes são estimulados a exercitarem a linguagem científica escolar na medida em que o emprego de conceitos é requerido para construção das respostas. Por 
conseguinte, uma disputa de Electron Escape pode se configurar como um contexto propício à investigação da significação e compreensão de conceitos, dado que durante a interação, mediada pela linguagem e pelo jogo, eles precisam pronunciar seus enunciados e passar a palavra ao próximo oferecendo a oportunidade de compreensão responsiva.

Pereira, Ostermann e Cavalcanti (2012) reconhecem a natureza social das aulas de Ciências e utilizam os estudos socioculturais de Vigotski e Wertsch para explorar a estreita relação entre a origem social das funções mentais e o uso de instrumentos e signos. Ancoramo-nos nesse marco teórico para compreender que as interações discursivas entre os jogadores são fundamentais para a utilização do jogo Electron Escape enquanto ferramental cultural. Entendemos que a interação social dos estudantes, em uma aula de Física, constitui um cenário sociocultural particular no qual a ação mediada e as ferramentas culturais estabelecem um vínculo entre os processos mentais humanos (WERTSCH, 1999).

\section{Metodologia}

Realizamos uma pesquisa qualitativa e do tipo estudo de caso. Escolhemos tal metodologia por delimitarmos as fronteiras de análise com o intuito de aprofundar nas particularidades do contexto definido: a disputa de uma partida do jogo Electron Escape por estudantes em uma aula de Física na primeira série do ensino médio, a qual possui sentido singular diante da realidade (LÜDKE; ANDRÉ, 2013). Nela, buscamos descrever as ações no contexto em que ocorreram para ilustrar um tópico da investigação (YIN, 2003).

A partida envolveu 12 estudantes da primeira série do ensino médio de uma escola da rede estadual de Vila Velha, no Espírito Santo, no terceiro trimestre de 2018, no fim do ano letivo. A pesquisa foi devidamente autorizada por todos os participantes, resguardando-se o sigilo dos registros e o anonimato dos sujeitos. A fim de preservar a identidade das pessoas envolvidas, empregamos pseudônimos para designar todos os sujeitos.

O objetivo pedagógico da atividade foi promover um momento no qual os alunos pudessem revisar o conteúdo e introduzir uma nova ferramenta, uma vez que nenhum tipo de jogo educativo havia sido utilizado durante todo o ano letivo. Além disso, as aulas expositivas-dialogadas de revisão, aparentemente, não estavam surtindo o efeito desejado com os discentes. A aula em que o jogo foi utilizado teve duração de 55 minutos. A professora reuniu os estudantes e eles se alocaram em três grupos de quatro membros. Em seguida, a docente apresentou o jogo aos alunos e explicou as regras e o funcionamento, e então foi iniciada a partida, cujo tempo médio de duração foi 40 minutos.

Escolhemos $^{6}$ o jogo Electron Escape pelo fato de ele colocar os jogadores em situações (as perguntas do jogo) nas quais o conhecimento científico é requerido e avaliado. Ao responder as perguntas (ou não) o aluno pode fornecer indícios do conhecimento adquirido nas aulas, bem como eventuais lacunas remanescentes. $\mathrm{O}$ caráter discursivo e

\footnotetext{
${ }^{6}$ A professora que conduziu a atividade é a segunda autora deste manuscrito.
} 
aplicado das questões possibilita a utilização de termos científicos na construção das respostas, as quais devem ser avaliadas pelo grupo em comparação ao modelo científico fornecido no jogo.

Para a produção de dados escolhemos as interações verbais dos estudantes coletadas durante a realização da partida, via registros de áudio. Um celular, com o modo gravação de áudio ativado, foi colocado sobre cada uma das mesas em que ocorreram as partidas. Temos utilizado esta estratégia para a coleta de áudio, uma vez que o telefone sobre a mesa facilmente se mimetiza. A partir das interações, selecionamos trechos nos quais os alunos interagiam mediados pela linguagem e o jogo. Tais trechos passaram por um processo fidedigno de transcrição (ocorrências de linguagem coloquial foram mantidas para preservar o contexto e a autenticidade dos enunciados). Eles nos permitiram analisar as interações verbais dos estudantes mediadas pelo jogo e pela linguagem por meio da teoria de Wertsch (1999). Organizamos um quadro com o fluxo das interações discursivas, explicitando os cinco elementos que compõem a ação mediada: cena, agentes, ato, propósito e agência.

Tais dados nos permitiram investigar algumas potencialidades de Electron Escape, enquanto recurso (meio mediacional), para o ensino da Física, como, por exemplo, se ele contribuiu para que os estudantes resgatassem e exercitassem os conteúdos trabalhados ao longo do ano letivo, bem como suas aplicações e correlações. Além de possíveis incorporações de termos científicos e suas utilizações em diferentes contextos, já que nos interessa analisar os indivíduos em "atividades práticas" (lembrar, raciocinar etc.). Pereira e Lima Júnior (2014, p. 523), ancorados em Vigotski (1994), afirmam que "é preferível falar em lembrar ou raciocinar como algo que se 'faz' do que falar em memória ou raciocínio como algo que se 'tem'".

Diante disso buscamos identificar se os estudantes realizaram tais ações, como a memória natural e a memória mediada. Segundo Pereira e Lima Júnior (2014), ancorados em Vigotski (1994), a memória mediada caracteriza-se pela intencionalidade dos agentes e pelo uso de meios mediacionais, ao contrário da natural, que utiliza a retenção de experiências reais como a base dos traços mnemônicos.

\section{Análises}

Em virtude do grande volume de dados, optamos por trazer apenas os áudios de dois dos três grupos, pensando também na extensão do manuscrito. Agrupamos os trechos selecionados das interações discursivas de dois grupos (I e II) em duas categorias de análise, as quais emergiram a posteriori. Os cinco elementos que compuseram a ação mediada são: 
Tabela 2 - Elementos da ação mediada.

Cena (contexto): Aula de Física envolvendo o jogo Electron Escape.

Agentes: Professora e estudantes (A1, A2, A3 e A4, do grupo I; e A5, A6, A7 e A8, do grupo II).

Ato: Disputa da partida de Electron Escape.

Propósito (objetivo) da professora: revisão do conteúdo e implementação de um novo recurso de ensino nas aulas de Física.

Agência (ferramentas culturais): linguagem (discurso), gestos e o jogo Electron Escape.

É importante ponderar que a ação mediada pode ter múltiplos propósitos, os quais variam de acordo com cada agente (WERTSCH, 1999). Por essa razão apresentamos os propósitos da professora (que integra a autoria deste texto), os quais foram estabelecidos durante o planejamento da atividade, e possuem um viés pedagógico. Os outros agentes da cena, os estudantes, possivelmente possuíam propósitos distintos, como pode ser visto no decorrer desta seção.

\section{V.1 A mediação por meio da linguagem e do jogo}

Nesta categoria trazemos trechos nos quais os estudantes realizaram a ação de lembrar e raciocinar de forma intencional, mediados pela linguagem e pelo jogo Electron Escape. Essas ações foram estimuladas de forma verbal (as perguntas) e pelo contexto da partida (que envolve a necessidade de responder corretamente as perguntas para avançar pelo tabuleiro).

A1(perguntando para A2): O que é necessário para definir a posição de um corpo?

A2: $O$ que é necessário...

A4: Professora, pode ajudar?

Professora: Você escolhe se quer ajudar ou não.

A2: Ponto de referência.

A1: Mesma coisa que referencial, né?! Tá [sic] certo.

O estudante A2 foi indagado sobre a definição da posição de um corpo, mas não conseguiu responder de imediato. Enquanto ele exercitava a ação de lembrar, a aluna A4 cogitou a possibilidade de ajudá-lo. A professora foi consultada e permitiu que os alunos decidissem se ajudariam ou não uns aos outros. É importante salientar que o manual de Electron Escape não prevê ajuda entre os jogadores para responder as perguntas. Esse elemento sugere a pluralidade de objetivos que a ação mediada pode ter (WERTSCH, 1999).

A2 respondeu e A1 comparou a resposta dada com a sugerida na carta. A fala desta estudante sugere um entendimento de que as respostas possuíam o mesmo significado. Ela 
chegou a afirmar que se tratava da "mesma coisa" e que, devido a isso, estaria "certo". Podemos entender que referencial e ponto de referência, nesse contexto, assumem o mesmo sentido, relativo a um sistema de coordenadas fixo em relação ao qual podemos definir as coordenadas de um ponto material. A segunda expressão pode ser considerada como mais próxima do vocabulário coloquial. Tal entendimento ancora-se em Vigotski (2009) que afirma que o sentido é sempre uma formação fluida, não estática, em que o significado é apenas um elemento desse arcabouço. Logo, o sentido relaciona-se a toda a frase, o que possibilita que palavras sejam substituídas em dado contexto sem que haja alteração de sentido, como no trecho acima.

A pergunta envolveu cinemática, conteúdo que fora trabalhado no primeiro trimestre do ano letivo. A1 e A2 tiveram que lembrar o conceito em questão, o primeiro para responder e a segunda para validar a resposta. Esse trabalho coletivo, mesmo em um jogo que funciona por turnos, compartilhou a responsabilidade entre os participantes, contribuindo para que mais jogadores exercitassem habilidades, como no trecho a seguir.

A3 (perguntando para A2): Energia mecânica associada a corpos em movimento.

A2: Movimento, energia...

A1: Isso a gente estudou.

A2: Energia gravitacional...

A1: Você estudou isso dois anos seguidos (risos).

A2: Tinha a gravitacional, a elástica... Qual era a outra? Ah, esqueci.

A3: Era cinética.

O conteúdo em questão era energia mecânica, que fora trabalhado no início do terceiro trimestre do ano letivo. A2 lembrou conceitos estudados associados à pergunta, citando energia gravitacional e elástica. A1 ratificou, de maneira jocosa, que aquele conteúdo fora estudado por eles. Após algum esforço, o jogador da vez admitiu que não se lembrava e, conforme as regras do jogo, a resposta da carta foi lida em voz alta para o grupo. Notamos nesse trecho o resgate de conteúdos associados à energia mecânica, que envolve a soma das energias cinética e potencial (elástica e gravitacional). Apesar de não ter acertado, A2 esteve bem perto de fazê-lo, o que pode ter sinalizado para esse aluno a necessidade de reforçar tal conteúdo.

Observamos uma tensão entre este agente e o os meios mediacionais com os quais ele operou. No primeiro caso, após certo esforço, A2 foi capaz de lembrar a resposta. No entanto, no segundo, ele recordou os dois tipos de energia potencial, mas não a cinética, que responderia corretamente a questão. Wertsch (1999) afirma que existe uma tensão irredutível entre os agentes e os meios mediacionais, porque não há como separá-los. Essa dimensão também pode ser vista no trecho a seguir, do grupo II.

A6 (perguntando para A8): Por que a posição da lua interfere nas marés? 
A6: Nossa, velho, essa eu sabia, que raiva! Caraca!

A7: A gente estudou isso, cara.

A8: Repete a pergunta.

A5: Da uma dica aê!

A6: Não tem como, se eu explicar, eu dou a resposta.

A8: Gravidade?!

A6: Isso!

A pergunta versava sobre a interação gravitacional, e A6 e A7 reconheceram a familiaridade com o conteúdo. A8, a quem a pergunta foi direcionada, solicitou que ela fosse repetida, e A5 pediu para que alguém ajudasse. No entanto, A6 afirmou que não conseguiria auxiliar o colega sem dar a resposta. Após alguns instantes, A8 disse apenas 'gravidade', e A6 validou como sendo correta a resposta. Isto poderia ser considerado insuficiente, já que a questão perguntava o porquê de o fenômeno ocorrer. $O$ estudante citou a palavra, não fornecendo maiores indícios sobre o significado que ele atribui a ela em relação ao entendimento da Ciência, que perpassa a ideia de atração das massas como origem da interação gravitacional, na Física Newtoniana.

Tais indícios poderiam ter surgido se o grupo de jogadores, ou a professora, solicitasse que A8 explicasse como a gravidade age no fenômeno em questão. Contudo, precisamos lembrar que a ação mediada possui múltiplos objetivos simultâneos, os quais podem ser divergentes (WERTSCH, 1999). A professora tinha o propósito de auxiliar os alunos na revisão do conteúdo, processo que envolve o aprofundamento na elaboração de resposta, preferencialmente empregando conceitos da Ciência escolar. No entanto, o grupo II, aparentemente, não tinha este objetivo, pois validou respostas distantes dos modelos científicos trazidos nas cartas, em certas situações.

Isto exemplifica a ponderação que fizemos no início desta seção sobre os múltiplos propósitos da ação mediada. Podemos supor que o propósito do grupo II era simplesmente “acertar" a resposta, o que explicaria o rigor questionável estabelecido para a validação. Wertsch (1999) nos diz que o uso de um meio mediacional, como a linguagem, está relacionado à intencionalidade do agente e a capacidade que ele possui de operar com tal meio. Por conseguinte, precisamos nos perguntar se os estudantes estariam aptos a pedir tais aprofundamentos nos modelos explicativos.

A3: Por que é mais é mais fácil boiar na água salgada do que na doce?

A1: Por causa do sal, que é mais denso?! Sei lá [sic]...

A3: Aceito.

A3: Por que o líquido sobe pelo canudo quando aspiramos?

A1: Porque... Calma... Ah, vou chutar. Sei lá, quando você puxa, a pressão diminui no canudo dentro da latinha e faz com que o líquido sobe pelo canudo... Sei lá.

A1: E aí, A2, aceitável? 
(A1 lê a resposta contida na carta)

A2 e A3: Ah, aceitável, aceitável.

Os trechos acima apresentam duas perguntas aplicadas. Em ambos os trechos o jogador A1 exercitou as ações de lembrar (os conteúdos trabalhados ao longo do ano letivo) e raciocinar (articulando os saberes para formular a resposta) mediadas pela linguagem e pelo contexto no qual se encontrava. As respostas dadas também precisaram ser validadas, dado que as cartas apresentavam as seguintes proposições, respectivamente: "a densidade da água salgada é maior que a da água doce" e "ao aspirar o ar do canudo, diminuímos sua pressão interna (em relação à pressão da parte externa, em contato com o líquido). Essa diferença de pressão faz com que o líquido suba".

A3 e A2 entenderam que havia compatibilidade em ambos os casos, e aceitaram as respostas elaboradas. Durante toda a partida nenhum dos três grupos recorreu à professora para validar alguma resposta dada. Entretanto, notam-se certas imprecisões nesse processo. A1 afirmou que o sal é mais denso, e não a mistura água com sal, como explicitado na carta. Tal resposta está incorreta, em relação ao aceito pela cultura da Ciência. O modelo desse aluno sinalizou, de certa forma, para um reconhecimento do fenômeno envolvido na situação, densidade.

$\mathrm{Na}$ questão do canudo A1 elaborou um modelo que podemos considerar um pouco mais consistente, mesmo não tendo sinalizado, de forma explícita, para a ideia de diferença de pressão. Notamos nas construções de A1 o esforço do estudante em empregar termos do discurso da Ciência escolar. Isso sinaliza para a busca pela apropriação e o reconhecimento do poder e da autoridade que essa cultura possui, pois a ação mediada é cercada por isso (WERTSCH, 1999). Esses elementos podem ter influenciado o grupo a validar as respostas, mesmo estando incompletas ou inconsistentes. Por consequência, vemos o frágil critério e rigor definidos pelos alunos para o processo de validação, o que foi feito sem interferência da professora. Vejamos o trecho a seguir, do grupo II.

A5: Por que não seria possível viajar de avião no vácuo?

A7: Porque é graças à pressão atmosférica que a gente pode viajar.

A5 (lendo a resposta contida na carta): $O$ avião se desloca empurrando o ar em sentido oposto, e também o utiliza para dar sustentação, por meio do fluxo que passa por baixo de suas assas.

A7: Então, é praticamente o que eu falei. Tá [sic] certo.

(grupo concorda e o jogo continua).

O estudante A7 formulou uma resposta empregando o termo 'pressão atmosférica'. A resposta da carta foi lida, conforme as regras do jogo, e o grupo aceitou a proposição de A7. Temos indícios do rigor e do critério adotados pelo grupo II para a validação das respostas, os quais podem ser entendidos como sendo tão flexíveis quanto do grupo I. A 
resposta de A7 não envolveu os elementos centrais contidos na carta (presença dos gases e terceira lei de Newton), e atribuiu o voo dos aviões a pressão atmosférica, o que diverge do entendimento aceito pela Ciência. Fatores como benevolência ou a não compreensão do modelo sugerido na carta também podem ter influenciado na aceitação da construção de A7 pelo grupo.

Momentos como esse nos fazem refletir sobre o grau de liberdade dado aos estudantes em Electron Escape para a realização desse processo. Por um lado, ele estimulou a comparação e validação das respostas, ações que exigem habilidades e competências importantes na aprendizagem em Ciências. Por outro, ele deu margem a validações incorretas, do ponto de vista da Ciência, e/ou pouco rigorosas. É importante destacar que não seria viável que a professora validasse todas as respostas dos grupos. Este estudo envolveu 12 estudantes devido ao contexto do fim do ano letivo. Entretanto, em nossa realidade lidamos com turmas com cerca de 40 alunos. Além disso, talvez, a presença da docente pudesse inibir, de alguma forma, os estudantes.

Esse é um ponto que precisa ser ponderado para futuras utilizações do jogo, pois é pouco provável, principalmente nas perguntas aplicadas, que um aluno elabore uma resposta literalmente igual à contida na carta. Isso faz com que seja necessário validar, o que envolve comparar a construção com o modelo científico da carta, buscando analisar o sentido dos signos no contexto em questão. Essa interpretação, por vezes, exigirá uma análise que apenas um membro mais experiente da cultura da Ciência pode realizar, como a professora. Por exemplo: no caso de um estudante que formula uma resposta que aponte para a direção do entendimento da Ciência, mas sem utilizar os termos científicos. Isso será validado ou não? É justo dizer que este estudante não sabe a resposta? Esse conjunto de variáveis corrobora a importância de se investigar a mediação por meio da linguagem no contexto do jogo Electron Escape, em virtude de os meios mediacionais restringirem e ao mesmo tempo possibilitarem a ação (WERTSCH, 1999).

\section{V.2 Da competição à cooperação}

Nesta categoria apresentamos os trechos em que a cooperação entre os participantes se refletiu em momentos nos quais o grupo auxiliou o jogador da vez a pensar nas respostas das questões. Ou seja, os exercícios de lembrar e raciocinar foram estimulados por outros elementos além da pergunta da carta e do jogo.

A2 (perguntando para A1): Nome dado à distância, em uma linha reta, entre a posição final e a inicial.

(A1 fica em silêncio por alguns segundos)

A4: Quando você sai de um lugar pro [sic] outro.

A1: Deslocamento!

A2: Âe! 
O estudante A1 foi indagado, mas não conseguiu responder de imediato. A4 decidiu ajudar e reformulou a pergunta contida na carta. Diante da "nova" questão, A1 foi capaz de responder. Essa situação tem a ver com fato de que a inserção de novas formas de mediação pode transformar a ação mediada (WERTSCH, 1999). Isto posto, a reformulação de uma pergunta pode alterar a mediação entre os jogadores.

A "nova" pergunta de A4 pode ser considerada bastante coloquial, de modo que 'trajetória' poderia ser uma resposta plausível e este conceito é diferente de deslocamento. Ambos envolvem a mudança de posição no espaço em relação a um dado referencial, mas deslocamento é a medida em linha reta da distância entre o ponto de partida e chegada, enquanto trajetória é a medida total do trajeto percorrido pelo corpo.

Mesmo diante da ambiguidade da nova pergunta A1 foi capaz de responder corretamente, o que pode sugerir uma lacuna conceitual nos jogadores envolvidos. A partir desse ponto da partida percebemos momentos de cooperação mais explícitos em ambos os grupos. Eles passaram a ajudar uns aos outros a solucionar as questões, principalmente por meio da reformulação das questões e de analogias. Isso reforça a importância de analisarmos as interações verbais desse processo.

A2: Em um ambiente com vácuo, uma pena e uma pedra são abandonadas da mesma altura. Qual deles atinge o solo primeiro?

A4: Ué, a pedra.

A1: Ah não (risos).

A2: No vácuo você não tem nenhum atrito, nem um vento... Nada. A pedra ou a pena chega primeiro no solo?

A4: Os dois.

A1: Mas ela já tinha respondido antes.

A2: Se fô [sic] assim ninguém vai acerta [sic], deixa o cara [sic].

No trecho acima a aluna A4 respondeu de imediato à pergunta que lhe foi direcionada. Ela sinalizou para um processo que pode ter origem em sua memória natural ao dizer que uma pedra chega ao solo antes de uma pena. Ou seja, o estímulo verbal pode ter causado a resposta, que tem base no senso comum (VIGOTSKI, 1994 apud PEREIRA; LIMA JÚNIOR, 2014).

A1 reprovou, de forma descontraída, a resposta dada, e A2 adicionou informações à pergunta para ajudar a jogadora da vez, sinalizando para o reconhecimento da ausência de atrito na queda livre. A partir das informações extras, A4 formulou outra resposta e acertou questão. A1 mencionou o fato de a jogadora ter dado uma resposta incorreta, em relação à contida na carta, na primeira tentativa. Todavia, A2 reiterou a posição de cooperação, e a decisão coletiva desse grupo social prevaleceu sobre a orientação do manual do jogo, que não prevê mais de uma chance de resposta. Esta decisão também se fez presente no grupo I, como pode ser visto no trecho adiante. 
A5 (perguntando para A6): Lei ou princípio que explica porque é mais seguro se locomover deitado do que de pé sobre um lago congelado.

A8: Ah, você lembra? Ela (a professora) fez até uma prova sobre isso.

A5: Qual o princípio físico? Tá [sic] muito fácil essa.

A5: Porque que você se movendo em pé é... Vai quebrar o gelo, tipo assim, e deitado não vai?

A7: Tá [sic] fácil.

A6: Eu já estudei isso.

A8: Você tá [sic] sentindo o que? (A8 aperta o braço de A6).

A6: Força?

A8: Não!

A6: Pressão?

Grupo: ah, até que enfim (misto de aplausos e risos).

Semelhante ao grupo I, os estudantes do grupo II ajudaram uns aos outros interpretando e reformulando algumas perguntas, com o intuito de facilitar o entendimento dos jogadores, além de permitirem mais de uma tentativa de resposta. No trecho acima A8 ratificou que o conteúdo fora estudado pela turma, mencionando sua cobrança em uma prova. O próprio aluno A6 reconheceu a familiaridade com o tema após A5 ajudá-lo, reformulando a questão. O jogador da vez permaneceu em dúvida e, diante disso, A8 utilizou um estímulo físico: apertou o braço do colega e perguntou qual era o "conceito físico" ali presente. A6 citou força e, após a negativa de A8, respondeu 'pressão', acertando a resposta e provocando aplausos do grupo.

A memória de A6 foi resultado de um estímulo externo, oriundo de A8 (apertar o braço), implicando em um ato intencional de lembrança. Isso nos permite entender esta situação como sendo o de memória mediada, na qual o estudante passou a ter controle sobre a própria memória por meio do estímulo dado. Isso tem a ver com o fato de os seres humanos influenciarem o comportamento alheio, e o próprio, por meio de signos e outros meios auxiliares, sendo tal controle de fenômenos psicológicos uma característica exclusiva da nossa espécie (VIGOTSKI, 1994 apud PEREIRA; LIMA JÚNIOR, 2014).

Os trechos acima apresentam a materialização da mudança de sistema de jogo: de competitivo para cooperativo. Electron Escape foi construído, a princípio, para ser um jogo exclusivamente competitivo. Os agentes (jogadores) perceberam uma affordance (possibilidade) e, por conta própria, decidiram alterar o sistema de jogo para o propósito que lhes era conveniente. Isto só foi possível porque a professora permitiu a flexibilização desta regra. Tal mudança tem relação com a já citada pluralidade de objetivos que a ação mediada pode ter, os quais, inclusive, podem ser conflitantes, como neste caso (WERTSCH, 1999).

Precisamos esclarecer o que entendemos por jogos competitivos e cooperativos. Antunes et al. (2019) afirmam que ambas as modalidades podem ter a mesma estrutura: objetivos, regras, participação etc. Todavia, os jogos competitivos são marcados pelo 
individualismo e a racionalidade instrumental, em que se joga para vencer o outro e a vitória individual é o resultado das ações. Nos jogos cooperativos a situação se inverte, pois o processo é tão importante quanto o resultado, de modo que os jogadores jogam uns com os outros, e não uns contra os outros. Por conseguinte, todos os participantes têm igual importância na partida, e compartilha-se tanto o sucesso quanto o fracasso.

$\mathrm{O}$ ato/vontade de vencer se faz presente tanto no jogo competitivo quanto no jogo cooperativo. Pelas regras do Electron Escape, apenas o primeiro a chegar a casa 'liberdade' é considerado vencedor. Todavia, os estudantes iniciaram um processo de cooperação para que os colegas acertassem as respostas e, com isso, a revisão de conteúdos foi potencializada. Tal fato nos permite entender que ganhar, para esses agentes, não era chegar ao fim do jogo, mas sim responder as perguntas "corretamente". A princípio, isso pode sugerir que o tabuleiro, em si, ficou em segundo plano, pois ser o primeiro a percorrê-lo parece não ter sido tão importante quanto responder as perguntas com os colegas, de modo que as cartas assumiram um papel principal.

Todavia, precisamos ponderar que o jogo não se resume às perguntas ou ao tabuleiro. Ambos compõem o jogo, sendo inadequado separá-los e discutir qual deles protagonizou a ação. As perguntas são a componente que estimulam o uso da linguagem científica escolar (foco deste artigo), e isto dá a impressão de que elas são o principal elemento. Entretanto, para sacar uma pergunta o jogador precisa jogar o dado e, dependendo, caminhar pelo tabuleiro.

É importante ressaltar que a competitividade é um aspecto integrante dos jogos regrados. Concordamos com a posição defendida por Szundy (2009) de que a competição e a cooperação são elementos inerentes à vida social, e em ambas o uso da linguagem ocorre. A competição em jogos não impede que o conhecimento seja construído colaborativamente, e pode impulsionar a criação de formas alternativas de colaboração, como observado neste estudo.

Vigotski (1994) e Leontiev (1988) afirmam que as regras de um jogo, associadas ao aspecto competitivo, permitem que o jogador avalie suas habilidades e destrezas em relação aos outros, potencializando a capacidade de autoavaliação. Além disso, o desenvolvimento e aperfeiçoamento das regras levam a ações que possibilitam a separação entre brinquedo e trabalho, essencial no decorrer da idade escolar e vida adulta. Desta forma, vemos que ambas as modalidades de jogo, cooperação e competição, possuem potencialidades e possibilitam o uso da linguagem.

Os dois grupos estabeleceram estratégias para auxílio mútuo na busca pelas respostas, o que corrobora o espírito de cooperação supracitado. Outro elemento comum aos grupos, e que parece ter influenciado diretamente o exercício de reformulação das perguntas, foi a dificuldade na interpretação das questões, como podemos ver adiante.

A6: Lei Física que estabelece a relação entre a resultante das forças que agem em um corpo e sua aceleração. 
A6: Não entendi nada.

A5: Eu também não.

A8: Relação entre força e aceleração...

A5: Caraca...

A8: Força e aceleração. Que fórmula tem força e aceleração?

A7: Pra [sic] achar não sei o que precisa de força e aceleração...

A8: Pensa na fórmula!

A5: Lei de Newton?!

A8: Qual?

A5: Segunda?!

A8: No chutômetro vocês tão [sic] legal (risos).

A6 leu a pergunta e em seguida sinalizou que não a compreendeu, assim como A5, que completou com uma interjeição de insatisfação. A8 auxiliou ao construir certo paralelo com a equação da segunda lei de Newton, e A7 usou a estratégia de preenchimento de lacuna, na qual uma frase é construída e cabe ao respondente completar o restante. A8 manteve o raciocínio com base na equação, o que ajudou A5 a responder a pergunta. Ele insistiu e A5 foi capaz de especificar a Lei de Newton em questão.

Esse trecho evidenciou o resgate do conteúdo de dinâmica, estudado no segundo trimestre, e sinalizou para o viés matemático que, aparentemente, foi marcante para os sujeitos. Neste caso, podemos considerar a equação da segunda lei de Newton como um meio que auxiliou a memória do estudante.

A1: Relação entre a massa de um corpo e o volume que ele ocupa.

A2: Não entendi.

A1: Relação entre a massa de um corpo e o volume que ele ocupa.

A1: Você tem um quilo de pena e um quilo de chumbo. Você tem a mesma quantidade de peso, mas um é mais...

A2: Pesado que o outro.

A3: Você tem um quilo de um e um quilo de outro...

A2: Densidade!

A1: Ah, o moleque é bom! (risos)

A3: Pegou poder de novo! Não é possível! (risos).

A2 foi indagado e não entendeu de imediato a questão. A1 releu a pergunta, mas A2, aparentemente, permaneceu sem compreender. A1 elaborou uma situação fictícia na qual o conceito em questão, densidade, se fazia presente, pela comparação das massas de sistemas distintos. Ela utilizou a estratégia de preenchimento de lacuna, como ocorrido no grupo II. É possível notar que a construção de A1 sinalizou para o uso indiscriminado dos conceitos de peso e massa, o que sugere uma dificuldade conceitual. 
A resposta de A2 não foi a esperada, o que levou o aluno A3 a intervir, ainda pela estratégia de destacar a equivalência de massas de dois sistemas. Após essa ação, A2 conseguiu acertar a resposta. Houve comemoração e, descontraidamente, A3 comentou o fato de A2 ter caído, mais uma vez, em uma casa do tabuleiro que permitiu que ele obtivesse uma carta de poder.

Os dois trechos acima demarcam a dificuldade dos estudantes na interpretação de algumas perguntas, a qual foi superada por meio do viés cooperativo adotado por eles para a partida. Os jogadores empregaram conceitos ao criarem pequenas "histórias" para ajudar os colegas que, inicialmente, não conseguiam responder as perguntas. Nessas "histórias" os conceitos em questão foram destacados de modo diferente do trazido pela pergunta da carta, o que ajudou o jogador da vez a acertar a resposta.

Tanto o jogador que respondia quanto os alunos que criavam as "histórias" exercitavam habilidades importantes e mostravam seus conhecimentos e lacunas, pois, como já comentado, notamos o uso incorreto, do ponto de vista da Ciência, de alguns conceitos físicos. Nossa hipótese é de que as atitudes de reformular as perguntas, fazer analogias e criar "histórias" foram impulsionadas pela dificuldade na interpretação da linguagem utilizada nas cartas e pelo espírito cooperativo entre os estudantes. $O$ trecho adiante sinaliza para tal entendimento.

A5: Área da Física que estuda o movimento dos corpos.

A5: Ele quer saber qual é a área, é tipo assim, ela estuda energia e essas coisas...

A7: Qual é a pergunta mesmo?

A5: Área da Física que estuda o movimento dos corpos. As perguntas elas são muito... Assim, do jeito que ela tá [sic] fazendo é difícil, mas depois que você lê a resposta fica fácil.

(A7 continua em silêncio pensando)

A5: quer que eu fale a resposta? É mecânica.

A7: Ah, sabia!

A aluna A5 apontou para a dificuldade em compreender as questões da forma como foram postas nas cartas. Essa dimensão ressurgiu em um comentário feito pela estudante no pós-jogo, no qual foi dito que "as perguntas deveriam ser menos complicadas, porque isso me confundiu durante o jogo". Não podemos negar que em alguns momentos da partida os alunos demonstraram certo entendimento dos conteúdos, mas a dificuldade em compreender a questão, em determinadas ocasiões, influenciou no desempenho. Esse cenário sugere a necessidade tanto de revisar as perguntas quanto de trabalhar a linguagem da Física.

As discussões sobre a linguagem das perguntas, os movimentos de reformulação delas, as "histórias" criadas e a estratégia de preencher lacuna são elementos que corroboram o papel fundamental da linguagem como meio mediacional em Electron Escape. Tais ações 
propiciaram a mobilização e construção de uma linguagem específica, a da cultura científica escolar. Embora a capacidade desta linguagem tenha se mostrado frágil, em alguns momentos, é possível notar o potencial do jogo para o estímulo e emprego da linguagem científica escolar, fazendo emergir algumas das potencialidades de Electron Escape para o ensino da Física.

Os trechos discutidos ao longo desta seção nos permitiram identificar aspectos potencializados pelo uso do jogo como recurso de ensino, como a já mencionada utilização da linguagem científica escolar em situações-problema, a participação na tarefa, o trabalho cooperativo impulsionado pela alteração nas regras, o exercício e resgate de conteúdos estudados ao longo do ano letivo. Tais elementos relacionaram-se à dimensão cooperativa adotada pelos alunos, a qual potencializou a utilização da linguagem na partida. Por meio do uso do jogo também foi possível identificar lacunas no conhecimento dos estudantes, evidenciadas nas perguntas não respondidas, nas respostas equivocadas e em algumas reformulações de perguntas, nas quais notamos o uso incorreto, do ponto de vista da Ciência, de alguns termos. Além disso, a validação de certas respostas pode ser interpretada como indício de assimilação incorreta de conceitos.

Esse cenário nos ajuda a (re)pensar as futuras implementações do jogo, bem como a dificuldade dos estudantes em interpretar algumas questões, as quais foram submetidas a um processo de revisão antes da utilização neste estudo. Esses apontamentos podem se constituir como subsídios importantes para um novo processo de revisão a ser realizado com vistas à outra utilização de Electron Escape.

Entendemos que as potencialidades identificadas e discutidas nas interações verbais dos estudantes, e arroladas acima, são fruto da relação estabelecida entre jogo e jogadores da forma como ocorreu na aplicação discutida neste texto. Tais potencialidades podem contribuir com o aprendizado da Física, e é possível que existam outras a serem reveladas, conforme Electron Escape seja incorporado a diferentes metodologias/abordagens de sala de aula.

O que queremos dizer com isso é que as possibilidades (affordances) existem ainda que os agentes não sejam capazes de percebê-las, e que o significado de um contexto está relacionado ao que é possibilitado a eles. Consequentemente, as contribuições de Electron Escape para o ensino da Física estão condicionadas à maneira como este recurso é incorporado à aula pelo professor, que pode ou não determinar a possibilidade de alteração no sistema de jogo, o rigor/critério para validar as respostas, entre outros.

\section{Considerações finais}

Os objetivos pedagógicos da aplicação discutida nesta pesquisa nos levaram a suprimir as perguntas que envolvessem assuntos não trabalhados pela professora durante o ano letivo. Entre eles, a Física Atômica, ainda que o nome do jogo, o tabuleiro e algumas regras tenham sido ludicamente construídos para remeter a elementos deste campo. Reconhecemos que, para alguns, isto pode se constituir como uma dicotomia, a qual pode ser 
superada por meio da seleção de questões (como fizemos neste estudo). O professor tem total liberdade para delimitar os conteúdos a serem contemplados na partida, de acordo com seu planejamento e objetivos. Afinal, as potencialidades do jogo, e de qualquer outro meio mediacional, devem estar articuladas as intenções dos agentes.

Ao caracterizar as interações verbais dos estudantes, por meio da teoria da ação mediada de Wertsch (1999), notamos o movimento feito por eles na alteração do sistema de jogo, mediante a permissão da professora. A partida foi disputada de modo cooperativo, e isso potencializou o uso da linguagem científica escolar. Ao decidirem cooperar, os alunos permitiram mais de uma chance de resposta e auxiliaram uns aos outros reformulando as perguntas e criando "histórias" nas quais os conceitos físicos se faziam presentes. Isso porque em um jogo competitivo se tem uma relação ganha versus perde, entre os jogadores, ao passo que no jogo cooperativo a relação é ganha versus ganha (BRANDÃO, 2015). É importante destacarmos que esse processo parece ter relação com a dificuldade na interpretação de algumas perguntas.

Nas referidas ações foi possível identificar algumas potencialidades do jogo, enquanto meio mediacional para o ensino da Física, como sinalizar para saberes e lacunas do processo de ensino-aprendizagem dos sujeitos, bem como o uso da linguagem científica escolar em situações-problema, o resgate conteúdos trabalhados ao longo do ano letivo e o diagnóstico em relação ao conhecimento dos alunos. Isso nos permite entender que o uso de Electron Escape pode auxiliar no processo de revisão e estudo para avaliações.

Com relação à validação das respostas, que ocorreu sem a participação da professora, observamos frágeis critérios e rigor em determinados momentos, o que sugere benevolência e/ou dificuldade conceitual do grupo em tal processo. Isso traz implicações importantes para o (re)pensar do funcionamento do jogo, enquanto ferramenta, para futuras implementações, além de ratificar a importância da colaboração professor-aluno no processo de ensinoaprendizagem em sala de aula, dado que o trabalho com o parceiro mais capaz é indispensável para o processo de significação conceitual dos conteúdos científicos escolares.

Reconhecemos que a utilização de Electron Escape permitiu que os estudantes entrassem em contato com alguns conteúdos de Física já estudados, cumprindo o propósito da aula por meio dessa ferramenta cultural. Porém, essa revisão poderia ter sido potencializada a interação professora-alunos fosse mais presente, pois auxiliaria, de forma mais consistente (aumentado o rigor na validação das respostas), no processo de significação conceitual. Com isso temos subsídios para refletir sobre a condução de uma atividade envolvendo jogos, com vistas a novas intervenções. Porque existe uma pluralidade de concepções pedagógicas e modos de interação social a serem explorados, o que ratifica a necessidade de mais estudos sobre o uso de jogos nessas diferentes vertentes. 


\section{Referências bibliográficas}

ALVES, M. A. O modelo estrutural do jogo hermenêutico como fundamento filosófico da educação. Ciência \& Educação, v. 17, n. 1, p. 235-248, 2011.

ANTUNES, J.; NASCIMENTO, J. B. D.; BERNARDINO, M. C. R.; QUEIROZ, Z. F.; CARVALHO SILVA, J. L. Jogos cooperativos e mediação da leitura: por que não na biblioteca pública? Perspectivas em Ciência da Informação, v. 24, p. 3-24, 2019.

BODEVAN, J. A de S; DAHER, C. T. Ensino de Física no ensino médio e educação de jovens e adultos: produção, validação e aplicação de jogos da memória sobre processos de propagação de calor. In : AMADO, M. V. (org) et al. O professor-pesquisador no ensino de Ciências. Curitiba: Appris, 2020. p. 181-199.

BRANDÃO, C. R. O jogo das palavras-sementes e outros jogos para jogar com palavras. São Paulo: Cortez, 2015.

CUNHA, M. B. Jogos no ensino de química: considerações teóricas para sua utilização em sala de aula. Química Nova na Escola, v. 34, n. 2, p. 92-98, 2012.

DRIVER, R.; ASOKO, H.; LEACH, J.; MORTIMER, E. F.; SCOTT, P. Construindo conhecimento científico em sala de aula. Química Nova na Escola, São Paulo, n. 9, p. 31-40, 1999.

DZIOB, D. Research in Science Education, 2018.

https://doi.org/10.1007/s11165-018-9714-y

GARCEZ, E. S. C. O lúdico em ensino de química: um estudo do estado da arte. 2014. 142 f. Dissertação (Mestrado em Educação em Ciências e Matemática) - Universidade Federal de Goiás, Goiânia.

GIORDAN, M. Computadores e linguagens nas aulas de Ciências. Ijuí: Unijuí, 2008. 368 p.

LEMKE, J. L. Talking Science: Language, Learning and Values. Norwood, New Jersey: Ablex Publishing Corporation, 1990, 276p.

LEONTIEV, A. N. Os Princípios Psicológicos da Brincadeira Pré-Escolar. In: VYGOTSKY, L. S.; LURIA, A. R.; LEONTIEV, A. N. Linguagem, Desenvolvimento e Aprendizagem. Editora da Universidade de São Paulo, 1988. 
LOPES JÚNIOR, A. D.; MORAES, B. M.; GONÇALVES, R. M. P. Linguagem e formação de conceitos: uma leitura a partir da escola de Vigotski. Fórum Linguístico, v. 17, n. 2, p. 4895-4908, 2020.

LÜDKE, M.; ANDRÉ, M. E. D. A. Pesquisa em Educação: abordagens qualitativas. 2. ed. Rio de Janeiro: EPU, 2013. 128 p.

LUDOVICO, M. M. Proposta de um jogo didático para a abordagem do tema Física de Partículas com alunos do Ensino Médio. 2017. Dissertação (Mestrado em Física) Universidade Federal do Espírito Santo.

LURIA, A. R. Curso de psicologia. Rio de Janeiro: Civilização Brasileira, 1991.

MARTINS, L. M. Desenvolvimento do pensamento e educação escolar: etapas de formação de conceitos à luz de Leontiev e Vigotski. Fórum Linguístico, v. 13, p. 1572-1586, 2016.

MARX, K.; ENGELS, F. A ideologia alemã. Rio de Janeiro: Civilização Brasileira, 2007.

MELO, M. G. A. O Jogo Pedagógico no Ensino de Física. 1. ed. Curitiba: Editora Appris, 2015. v. 1.91p.

MORTIMER, E. F.; SCOTT, P. H. Meaning making in secondary science classrooms. Maidenhead-UK: Open University Press, 2003, 160 p.

NETO, H. S. M.; MORADILLO, E. F. O Lúdico no Ensino de Química: Considerações a partir da Psicologia Histórico-Cultural. Química Nova na Escola, v. 38, n. 4, p. 360-368, 2016.

NEWMAN, F.; HOLZMAN, L. Lev Vygotsky: cientista revolucionário. Tradução: Marcos Bagno. São Paulo: Edições Loyola, 2002.

OLIVEIRA, L. A.; SÁ, E. F.; MORTIMER, E. F. Transformação da Ação Mediada a partir da Ressignificação do Uso de Objetos Mediadores em Aulas do Ensino Superior. Revista Brasileira de Pesquisa em Educação em Ciências, v. 19, n. 1, p. 251-274, 2019.

OLIVEIRA, F. I. S.; RODRIGUES, S. T. Affordances: A relação entre agente e ambiente. Ciências \& Cognição, v. 9, n. 1, p. 120-130, 2006.

OLMSteAD, M. Using Games to Understand Physics Concepts. The Physics Teacher, v. 57, n. 5, 2019. https://doi.org/10.1119/1.5098918 
PEREIRA, R. F. Desbravando o Sistema Solar: um jogo educativo para o ensino e a divulgação da Astronomia. In: NEVES, M. C. D. (Org) et al. Da Terra, da Lua e Além. Maringá: Massoni, 2007, p. 167-185.

PEREIRA, R. F. Desenvolvendo jogos educativos para o ensino de Física: um material didático alternativo de apoio ao binômio ensino aprendizagem. 2008. Dissertação (Mestrado em Educação para a Ciência e o Ensino de Matemática) - Universidade Estadual de Maringá, Paraná, Brasil.

PEREIRA, A. P. de; LIMA JUNIOR, P. Implicações da perspectiva de Wertsch para a interpretação da teoria de Vygotsky no ensino de Física. Caderno Brasileiro de Ensino de Física, v. 31, n. 3, p. 518-535, 2014.

PEREIRA, A. P.; OSTERMANN, F. A aproximação sociocultural à mente, de James V. Wertsch, e implicações para a educação em Ciências. Ciência e Educação, v. 18, n. 1, p. 23 39, 2012.

PEREIRA, A. P.; OSTERMANN, F.; CAVALCANTI, C. J. H. Um exemplo de "distribuição social da mente" em uma aula de Física quântica. Ciência e Educação, v. 18, n. 2, p. 257 $270,2012$.

REZENDE, F.; TRINDADE, M. Jogos de linguagem e mudança discursiva na interação compartilhada de estudantes com sistema hipermídia. Revista Brasileira de Pesquisa em Educação em Ciências, v. 11, n. 1, p. 81-102, 2011.

RIBEIRO, R. K. P. Produção de significados utilizando o Jogo Planeta Química com base na Teoria da Ação Mediada. 2018. Dissertação (Mestrado) - Programa de Pós-graduação em Ensino de Ciências e Matemática/ccet, Universidade Federal do Maranhão, São Luís.

ROCHA, J. S.; GOIS, J. Aproximações entre as concepções de jogos e a Teoria da Ação Mediada no Ensino de Ciências. In: ENCONTRO NACIONAL DE PESQUISA EM EDUCAÇÃO EM CIÊNCIAS, XI, 2017, Florianópolis. Anais... XI ENPEC, Florianópolis: UFSC, 2017.

SEPUlVEDA, C. A. S.; REIS, V.; ALMEIDA, M. C.; CARNEIRO, M.C.L.; AMARANTE, A. L. A. P. C.; EL-HANI, C. N. Uma ferramenta sociocultural de análise da apropriação da linguagem social da Ciência escolar. In: ENCONTRO DE NACIONAL DE PESQUISA EM EDUCAÇÃO EM CIÊNCIAS, VIII, 2011, Campinas. 
SILVA, K. J. F.; MACHADO, A. R.; SILVA, F. R. F.; MARTINS, M. M. M. C.; BEZERRA, M. A. A utilização de jogos didáticos no ensino de biologia: uma revisão de literatura. Educere et educare, v. 13, n. esp., p. 1-14, 2017.

SOUZA, E. J.; MELLO, L. A. O uso de jogos e simulação computacional como instrumento de aprendizagem: campeonato de aviões de papel e o ensino de Hidrodinâmica. Caderno Brasileiro de Ensino de Física, v. 34, n. 2, p. 530-554, 2017.

SZUNDY, P. T. C. Jogos de linguagem como gêneros no processo de ensino-aprendizagem de LE para crianças. Trabalhos em Linguística Aplicada, v. 48, n. 2, p. 275-294, 2009.

TRAZZI, P. S. S. Ação mediada em aulas de biologia: um enfoque a partir dos conceitos de fotossíntese e respiração celular. 2015. Tese (Doutorado em Educação) - Programa de Pós-graduação em Educação, Universidade Federal do Espírito Santo, Vitória.

VARGENS, M. M. F.; NIÑO-EL-HANI, C. Análise dos efeitos do jogo Clipsitacídeos (Clipbirds) sobre a aprendizagem de estudantes do ensino médio acerca da evolução. Revista Brasileira de Pesquisa em Educação em Ciências, v. 11, n. 1, p. 143-168, 2011.

VIGOTSKI, L. S. A formação social da mente: o desenvolvimento dos processos psicológicos superiores. 5. ed. São Paulo: Martins Fontes, 1994. 224 p.

VIGOTSKI, L. S. Teoria e método em Psicologia. São Paulo: Martins Fontes, 2004. 536 p.

VIGOTSKI, L. S. A construção do pensamento e da linguagem. São Paulo, SP: Martins Fontes, 2009.

VILAS BOAS; MACENA JUNIOR; PASSOS. RPG pedagógico como ferramenta alternativa para o ensino de Física no Ensino Médio. Caderno Brasileiro de Ensino de Física, v. 34, n. 2, p. 372, 2017.

WERTSCH, J. V. La mente enacción. 1. ed. Buenos Aires: Aique, 1999.

YIN, R. K. Estudo de Caso: planejamento e métodos. 2. ed. Porto Alegre: Artmed Editora S/A, 2003, $205 \mathrm{p}$. 